\title{
Service And The Millennial Business Student: The Motivating Influence Of An E-Book Class Project
}

William W. Arnold, Pepperdine University, USA

\begin{abstract}
A commitment to voluntary service that benefits others was reinforced for students who authored an e-book on service as a class project in a senior business course. The immersive experience of writing short essays that focused on service shifted students' motivations toward service and solidified their intentions to continue with service after graduation. The article reviews millennials' characteristics and their activities related to volunteering services. The concerns of generations covering the past 100 years illustrate the shift from physical hardship and a rudimentary standard of living in earlier times toward present-day issues of millennials, namely economic security, technology change, globalization and meaningfulness in life and careers. A 4-stage model shows how student engagement in creating the e-book influenced commitment to service. The stages include (a) salience (being tasked with the assignment), (b) reflection (thinking about service), (c) internalization (deciding about service in their own lives), (d) commitment-action (resolve to actively integrate service into future life). Examination of millennials' values and work styles indicated the e-book as a class project matched their preferences. Each of 5 teams was tasked to complete deliverables, which the students produced operating under a "leaderless classroom" structure. Corporations that encourage employees to offer pro bono services have recognized benefits to their employees, reinforcing the need for business education programs to include service-related experiences.
\end{abstract}

Keywords: Millennial Service; Millennial Volunteering; Business Curriculum; Student Service; E-Book Class Project

\section{INTRODUCTION}

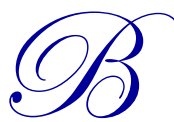

usiness students of today select from an array of curriculum variations and pedagogical strategies as they pursue their educations throughout the U.S. and globally. Among the plethora of offerings, two possibilities have not yet become common: (a) service as a topic that merits curricular focus; and (b) e-book authoring and publication as an instructional tactic. Service, in the context of education, often refers to service learning, which typically emphasizes community and civic activities. Service as the subject of this article encompasses service learning and formal volunteering that advances the missions of organizations created to meet human needs, and also extends beyond formal services to include one-time and recurring activities instigated by social media, interpersonal relationships, and individual commitments to service.

Service-learning may be viewed as a supplement to academic learning, and may function to integrate academic education with the challenges students may expect to face in non-academic life. Godfrey, Illes, and Berry (2005) concluded that service-learning presents a needed counterpoint to the transactional character of business education. Service learning can transcend students' education within the broader context of real relationships, which often require reflective thinking, interpersonal give and take, and a sense of responsibility to get tasks completed. Pre- and post-test comparisons of undergraduate business education students who participated in service-learning projects based on a survey by Poon, Chan, and Zhou (2011) showed an increase in students' sense of social responsibility and ethical and moral behavior.

Do business educators have a role in encouraging students to be service-minded? Data on volunteerism (U.S. Bureau of Labor Statistics, 2016) indicated a stagnating or declining trend in volunteering nationally. Participation by 
millennials was the lowest of the generations. However, the statistics for the generational classes have not included informal volunteering and impromptu acts of service instigated by groups and individuals. Do the statistics accurately represent level or declining voluntarism? Is it now appropriate to raise new questions about the level of interest in volunteering services? Studies of millennials by numerous agencies and organizations have identified shifts in both the values millennials hold and in the ways millennials choose to conduct their lives and careers (Fry, 2016; National \& Community Service, 2014; Sullivan \& Clolery, 2014; U.S. Chamber of Commerce Foundation, 2012). Corporations have begun to endorse volunteerism, including encouraging employees to provide pro bono professional services to non-profit organizations. Employers are recognizing that supporting employees in volunteer roles improves engagement, and employees are seizing the opportunity to take advantage of this employee benefit (Chandler, 2015; Moffat, 2015).

This article offers the experience of students in a senior level business course whose individually written essays on the subject of service were produced as an e-book. Inspection of the contents of the essays indicates the students deepened their commitment to performing in service capacities, and they integrated service as a proactive aspect of their future business and personal lives.

\section{SERVICE BY MILLENNIALS}

The U.S. Bureau of Labor Statistics (2016), which uses the slightly expanded definition of millennials to refer to those born between the years 1982 and 2000, reported that millennials now outnumber baby boomers. A summary of the generational names and time spans is presented in Table 1.

Table 1. Generations, Time Spans, and Ages

\begin{tabular}{l|c|c}
\hline \multicolumn{1}{c}{ Generation } & Year of Birth & Age in 2016 \\
\hline Millennials & $1980-1999$ & $17-36$ \\
\hline Generation X & $1965-1979$ & $37-51$ \\
\hline Baby Boomers & $1946-1964$ & $52-70$ \\
\hline Silent Generation & $1928-1945$ & $71-88$ \\
\hline Greatest Generation & Before 1928 & Over 88 \\
\hline
\end{tabular}

Source: Based on U.S. Census and Pew Research Center data (Fry, 2016).

Research on volunteering and civic engagement among millennials (National \& Community Service, 2014), provided a profile of volunteering based on 2013 data as follows:

- $\quad 21.7 \%$ of millennials volunteer

- 15.7 million volunteers

- 1.6 billion hours of service

- $\$ 36.5$ billion of service contributed

- 36 median hours of service (p. 1)

According to the same cited source, more than $60 \%$ of the millennial respondents indicated they had posted on social media at least once in the past week.

\section{THE E-BOOK PROJECT}

During the spring semester of 2016, the 24 students in a senior seminar course on current issues in management learned that collectively, as a class project, they would become authors of a book that would be available online. Their professor designated the title and subtitle Touch: A Millennial Conversation about Great Leadership, Service, and Purpose. Students prepared short essays on each of the subtitle themes. Most of the service-related comments were contained within the service section of the book, although the article included service comments that appeared in other sections, including short bios of each of the students. The 24 students represent a microcosm that generally matches the profile of millennial students. The class composition, however, is judged to be especially high in diversity: Of the 24 students, $60 \%$ were born outside the U.S. and $80 \%$ had lived or studied outside the U.S. 
The professor conducted the class using the "leaderless organization" model, a bottom-up, decentralized organizational structure described by Brafman and Beckstrom (2006) in their book The Starfish and the Spider: The Unstoppable Power of Leaderless Organizations. These authors depicted the growing prevalence of organizations that thrive, seemingly propelled by their own volition, as many online businesses and social networks have experienced. Millennials are well adapted to this phenomenon. The professor divided the students into five groups. Each member was selected to achieve diversity and a balance of capabilities. Additionally, each team was assigned a specific deliverable, namely, timeline, cover/graphics, content sequence, production, and editing. The teams had no assigned leaders, but one individual on each team was designated to communicate with the professor. The teams were instructed to organize and operate as they wished, with no team needing to apply practices similar to any other. The class met twice weekly for 14 weeks. The classroom structure for each meeting was limited to the professor's brief presentation of one of the readings in the class syllabus. Students chose the music that would be played during the class and in most other ways operated autonomously. Each group gave presentations to update progress and request input from class members at critical points.

\section{SHIFT IN MOTIVATION TOWARD SERVICE COMMITMENT}

The class e-book project progressed through the 14 weeks and concluded successfully. The students developed short essays on the themes of the book, which were purpose, service, and leadership. No restriction was placed on the material students used to develop the essay content. Class-assigned readings covered a wide range of topics related to motivation, leadership, business management, personalities in business, and business principles. The readings acted as prompts for the students. They augmented the students' own imaginations, stories, thoughts, and feelings.

The theme of service was familiar to the students through their individual past experiences, including service in school clubs, community charitable events and fundraising activities. The assigned service topic, coupled with the need to clarify and write their thoughts to be published, was a call to awaken a fresh approach.

\section{Affirming Statements}

Table 2 shows abbreviated student comments that indicate commitment to taking action in integrating service activities into the conduct on the students' ongoing lives. The reader will note that first names, which are pseudonyms for purposes of protecting student identifies, follow each comment. 
Table 2. Affirming Comments Related to Commitment to Service

\begin{tabular}{|c|c|}
\hline Name & $\begin{array}{c}\text { The Most Affirming Statements Related to Commitment to Service } \\
\text { (Parsed for Brevity) }\end{array}$ \\
\hline Alan & Service sprouts from the heart and shows in actions. \\
\hline Alana & Service leadership is part of every setting and relationship we have. \\
\hline Alexander & Touch others to serve themselves and others. \\
\hline Allison & Caring for others...is a great act of service. \\
\hline Anthony & It is important to serve the well-being of others. \\
\hline Cameron & View service as a way of life. \\
\hline Christopher & Serving others is my vocation in life. \\
\hline Christian & A business must serve the community, its employees, and its customers. \\
\hline Clair & I will use my successes to help others. \\
\hline Cynthia & I am happiest when I can serve a greater purpose. \\
\hline Eve & Service...is not an afterthought following monetary success. \\
\hline Jacob & I want to help people change the world. \\
\hline Jessica & My biggest passion in life is to help others. \\
\hline Jason & Service requires giving and offering all the time. \\
\hline Jordan & Service is an honor, a privilege, and a blessing \\
\hline Michael & I view serve as a way of life. \\
\hline Montgomery & Make [service] an everyday exercise. \\
\hline Nicholas & Service is the glue that holds the relationship together. \\
\hline Nicole & Service involves engaging employees, customers, and society. \\
\hline Rachel & My purpose is to serve others. \\
\hline Rhett & What can I do to help? To serve? \\
\hline Robert & We should routinely reach out in kindness and understanding... \\
\hline Scout & Service is not just something to be done in the future when one has enough time. \\
\hline Sydney & It's time to become the person who helped us when we needed help. \\
\hline
\end{tabular}

\section{A 4 Stage Model of Influence from Salience to Commitment-Action}

Figure 1 shows a progression that has been applied to decision making. It has been used to describe the process by which people become motivated to act on external stimuli. Well known among sales people as the AIDA principle (Strong, 1925), the acronym stands for awareness, interest, desire, and action. The principle represents the necessity to attract attention before advancing along the progression to interest, then to desire, and finally to the point of decision.

Figure 1. Progression of stages an individual passes through from awareness to decision and action. Adapted from Strong (1925).

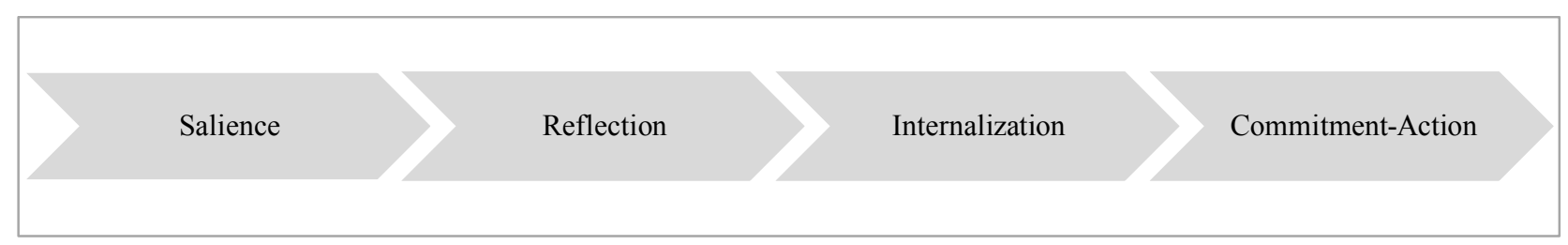

The 4 stages depicted in Figure 1, salience, reflection, internalization, commitment-action, represent the development of student predisposition toward integrating service into their lives as they processed their thoughts and developed their essays. Students' comments related to service were examined along the 4-stage continuum. Comments about service were identified and grouped into one of 4 stages. Grouping was accomplished according to criteria including: more than definition, apparent depth of reflection, richness of expression, sense of intensity, breadth of conviction, and intention to act. The commitment-action stage presents comments of students who were most emphatic in expressing their views about the merits of service and their intentions to actively follow through with offering service. Each of the 4 stages is described briefly followed by student comments that demonstrate the characteristics of that stage. 


\section{Salience}

The task of preparing an essay on service for the class book project undoubtedly cast a new light on service for the students. This task intervened in their thinking about service. It interrupted them and required them to pay attention. At this stage comments tend to be definitions.

Service is serving others by putting their needs above my own. Allison

Service is an act of humility that places others before ourselves. Jordan

\section{Reflection}

As students gave notions of service their attention, their framework might have included their past conditioning, family and cultural influences, and service experiences with peers. Their reflections may have included the impact of past service experience: perceptions of meaningfulness, who benefited, and whether it seemed important or insignificant.

Service to others ennobles us. Robert

A focus on service is essential in helping to maintain a healthy balance and to remind us that we exist in a society, and a society can only function when people care for each other. Allison

Life is more than just about me. It is about us... as a society... as a nation....as humanity. Allison

Customer service is the glue that holds the relationship together. Nicholas

Service is not just something that a person thinks he or she can do in the future when that person makes enough money, or has enough time. Scout

\section{Internalization}

In this third stage students expressed a position that favored service as something that should be done. Several students articulated the idea that performing service is a guiding life principle. Students considered their own past needs and the times when someone was there to help them. Also, to be noted are the more complete comments which offer greater detail and more powerful aspects of delivering service.

The impact service can have on the world can lead to immense change... Rachel

The selfless act to put another's best interests first is powerful. Rachel

Service is something which is not just beneficial to others, but it is beneficial to ourselves as well. Michael

Caring for others...is a great act of service that should not be forgotten. Allison

Service is the idea of putting someone or something else above ourselves. Cynthia

Service is acting out of your heart for the good of another. ...I believe service, in a way, connects us. Alexander

[Service] must be a stand-alone act done for the sheer joy and honor of serving another. Jordan

Service is not about getting. It is about giving. Clair

If we harness the need to serve, nothing limits the good we can do for humanity. Jacob 
We are now able to incorporate service everywhere we go. Jacob

Service is about unselfish kindness and generosity, acts that show goodness, that give meaning to our lives and, above all, that sustain and dignify the lives of others. Robert

Service involves going outside one's personal interests to engage employees, customers, and, ultimately, society. Nicole.

\section{Commitment-Action}

The commitment-action stage represents reaching a conviction that being of service to others is positive and important. Again, the student statements are richer in specificity and show variety along the dimensions of service. Comparing student comments in the first stage, salience, with comments in the commitment-action stage shows a meaningful contrast toward an action-oriented endorsement of service.

Service is a responsibility of every human being. Jessica

I now look beyond what I want to achieve for myself alone, having learned that it is important to serve the well-being of others, and not pursue only my own dreams. Anthony

Service is needed and should be welcomed as part of one's life. Alexander

Service is not a means to an end but $i s$ the end. Service is an honor, a privilege, and a blessing. Jordan

Millennials [must] realize the importance of being servant leaders...in every setting and relationship we have. Alana

Finding something we want to serve greater than ourselves...creates a new level of energy inside of us. Clair

Service is a selfless act. Service betters those around us, and service is essential. Rhett

[Service] is morally justifiable. Greed is not. Jacob

It is time to give back and become the person who helped us when we needed help. Sydney

I like to think I'll leave this Earth in a better state than when I first entered it. Montgomery

Service is something that sprouts from the heart, and it shows in a person's actions. As a result, these actions make positive contributions to the community, and even the world. Alan

My biggest passion in life is to help others... Jessica

My purpose is to serve others. Rachel

Serving others is my vocation in life. Through service, there is meaning to my life. Christopher

I personally view service as a way of life, the idea of putting someone else's needs before our own. Michael

I will find where I am happiest and can serve a greater purpose. Cynthia

It is my personal responsibility to continue acting out of service, not to receive anything in return, but to touch others in a way so they may find it within themselves to do the same for themselves and for others. Alexander

I seek to ...use my skills, abilities, and successes to help others. Clair Service requires people to give and offer all the time. Jason 
Service...is the core foundation of the business, rather than a philanthropic afterthought following monetary success. Eve

A business must serve the community, serve its employees, and, finally, serve its customers. Christian

I will embark with determination in my eyes and compassion in my heart to do my part to help make this world a better place. Rhett

True service can be attained if we ingrain the daily thought of, 'What can I do today to help those around me? How can I service others?' Rhett

I want to change the world. I want to help people, and I want to help people change the world. Jacob

We should routinely reach out in kindness and understanding to people unlike ourselves. Robert

Throughout my everyday life, I try to make service a key aspect. Montgomery

Some individuals see service as a task. However, we should view it as a way of life. Cameron

Service is living our lives always extending a helping hand, and making this an everyday exercise. Montgomery

\section{A RATIONALE FORTHE INFLUENCE OF THE E-BOOK PROJECT}

In research by Ukleja and Jackson (2015) authenticity as a personal quality placed high on the priorities of millennials. They concluded that "Authentic leadership is transformational leadership, where one is motivated, inspired and even changed by the leaders they follow" (p. 1). Other qualities millennials value, according to the authors are humility, empathy, commitment to the growth of followers, development of new skills, leadership that takes a personal interest in their ideas, and an environment that welcomes them to share in decision making.

Social issues of greatest interest, as reported in The 2016 Millennials Impact Report: Wave 1 Trends (2016) are education, healthcare, employment/wages, crime, and human rights. According to Jenkin (2015), $62 \%$ of millennials want to work for a company that "makes a positive impact, half prefer purposeful work to a high salary, and $53 \%$ would work harder if they were making a difference to others" (p.1). A study by Kaifi, Nafei, Khanfar, \& Kaifi (2015) found that millennials are overachievers and are accountable for their actions. They are team oriented and enjoy working with others. Having grown up in a diverse world, they understand the importance of learning and embracing new perspectives. "Millennials like to have flexibility and dislike dealing with too many rules and regulations" (p.91). Meister and Willyerd (2010) in their article Mentoring Millennials stated that "Millennials view work as a key part of life, not a separate activity that needs to be 'balanced' by it. For that reason, they place a strong emphasis on finding work that's personally fulfilling" (p. 2).

What are employers experiencing with millennials? El-Attarash (2015) pointed out advantages to working with millennials. In the voice of millennials "We're digital, savvy, we're used to accessing information within seconds, and we are group-oriented. As the most diverse generation, we're also used to working with different ideas and opinions in team settings (p. 2). Findings of the Price Waterhouse Coopers Millennial Survey, Millennials at Work: Reshaping the Workplace (2008) indicated that millennials will be able to "influence the way they work and where and how they operate in the workplace" (p. 1). From his perspective as Chairman and CEO of Deloitte Consulting, Moffatt (2015) observed that millennials "have traits that are amazing for business" (p. 1). Millennials value authenticity, individuality and self-expression, but when it comes to fitting into a company culture, they may resist and, rather, "shape the company culture to fit them" (p. 1). However, Moffatt asserted, millennials expect to work to improve their lives in corporations and make their corporations stronger. His views reinforce the conviction that business can profit from millennials.

The millennial generation's differences have been the subject of significant research studies. Table 3 summarizes a compilation based on several of these. 
Table 3. Profile of Millennials' Characteristics, Work Preferences, and Valued Qualities

\begin{tabular}{l|l|l}
\hline \multicolumn{1}{c}{ Characteristics } & \multicolumn{1}{c}{ Work Preferences } & \multicolumn{1}{c}{ Valued Qualities } \\
\hline Meaningful work & Team oriented & Authenticity \\
\hline Impact, positive difference & Challenges, opportunities to learn & Humility \\
\hline Accountable for results & Flexible & Empathy \\
\hline Diverse backgrounds & Few rules/regulations & Personal interest by leaders \\
\hline Technology, digitally savvy & Work-life balance & Feedback \\
\hline Group oriented & Multi-task & Being entrusted \\
\hline Accept ideas and opinions & Autonomous & Being heard \\
\hline Express individually & Self expression & Opinions respected \\
\hline Self-directed & Share in decision-making & Allowed to take risks \\
\hline $\begin{array}{l}\text { Source: Based on 2016 Millennials Impact Report: Wave 1 Trends (2016); El-Atarash (2015); Jenkins (2015); Kaifi et al. (2015); Meister and } \\
\text { Willyerd (2010); Millennials at work: Reshaping the workplace (2008); Moffatt (2015); Ukleja and Jackson (2015). }\end{array}$
\end{tabular}

Contrary to largely commendable findings, though, research indicated that millennials can be seen as overly selfconfident and self-absorbed, making them difficult to integrate into the work setting (U.S. Chamber of Commerce Foundation, 2012). Gen X and older employees may not mesh well with millennials who do not understand the priorities of the earlier generations. A report by issued by Catalyst (2015) indicated the millennial generation, which will reach $50 \%$ of the workforce by 2020 , felt being in the same career position at the same level for more than a year was acceptable. Solomon (2016) in defense of millennials asserted that millennial employees care about organizational ethics and social responsibility.

\section{SHIFTS IN GENERATIONAL NEEDS}

Abraham Maslow (1954) contributed the fundamental thinking that lower level needs predominate and must be met before higher level aspirations can be realized. Maslow's highest level of attainment is self-actualization. Each generation has met its share of challenges, but the nature of those challenges has changed measurably. Over the past 100 years many hardships associated with living have been replaced due to advances in science, technology, and ease of communication which makes knowledge readily available. Many diseases have disappeared and life spans have lengthened. The pace of living has accelerated. Air travel, broadcast media, and digital technologies have introduced new choices in living and working. It appears likely that a significant subset of millennials are now able to live their lives with self-actualization as an aspiration, or a reality, in at least an aspect of their lives.

Figure 2 shows the pyramid associated with Maslow's (1954) model. Earlier generations shown at the bottom depict the path to higher levels over time. 
Figure 2. Events and concerns of generations over time. Hypothesis stimulated by Maslow (1954).

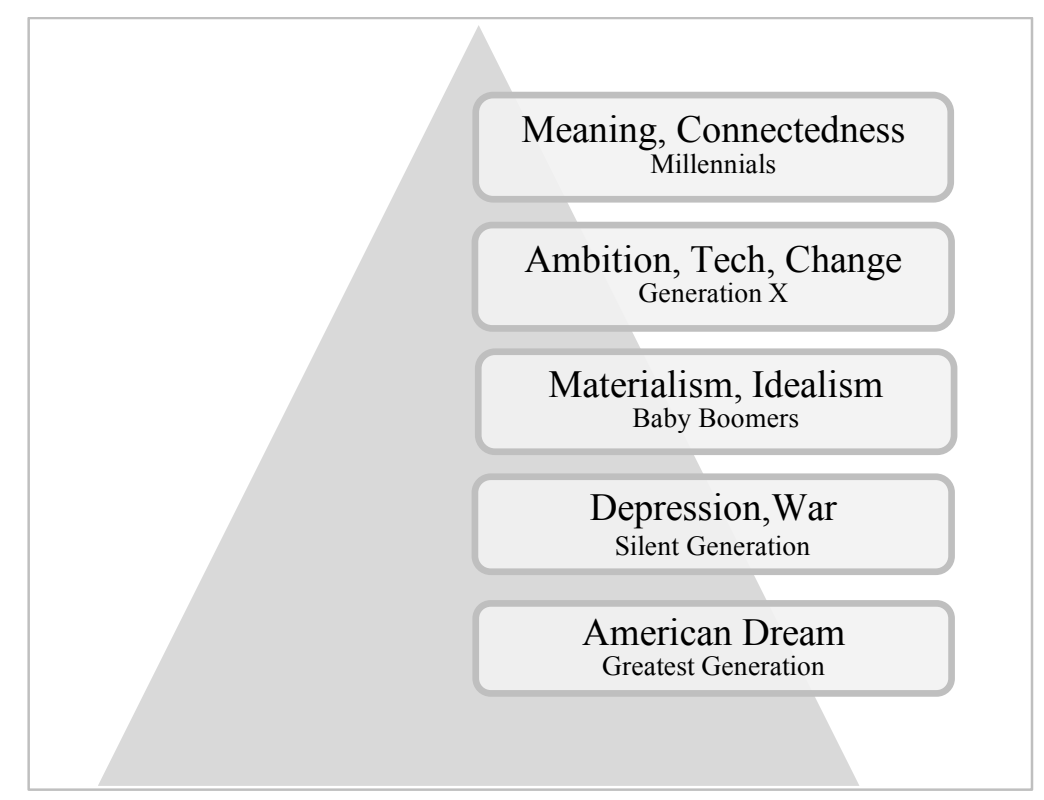

In an article published by the Harvard Business Review, Almquist, Senior, and Bloch (2016) identified fundamental elements of value in relation to products considered by consumers. At the most basic level is the need for functionality, with higher tiers representing emotional, life-changing, and social importance, and the apex representing self-transcendence.

Contemporary researchers have extended Maslow's model to explain and communicate human behavior. For example, Smith (2014) wrote about applying Maslow's model to employee engagement. She identified characteristics associated with disengagement, parallel to Maslow's survival level, then showed employees moving up the pyramid to higher levels: not engaged, almost engaged, engaged, and highly engaged (comparable to Maslow's self-actualization level). At self-actualization, employee intentions are be expressed as: What can I do for others? And how can I inspire others to do their best?

In a report issued by JC Global Services, Millennials and Work (2015) the authors observed that millennials were raised to believe their feelings and opinions matter; they need to be informed and trusted. Zhou (2016) asserted that employee engagement increases as needs are met. Engagement improves by opening new paths to meet higher level needs including belonging, being valued by leadership, and establishing open and trusting relationships. Engaged, self-actualized employees actively share their successes, knowledge, and ideas.

\section{CONCLUSION}

As cogently put by Zenisek and Stinnett (2014), "Service - whether elected, military, faith-based, or in the non-profit sector - brings people from across the country and across the aisle together to see eye to eye and learn from each other as they work for a shared purpose" (p. 1). The e-book class project demanded intense engagement by the students and immersed them in considering their positions regarding service. Examination of students' comments suggests that the process had a motivating influence on students' commitment to service. As millennials assimilate into corporations, their employers are increasingly honoring their values and work preferences, including assigning work that is meaningful and encouraging employees to engage in providing service to others. Preparing millennial business students to include service in their careers, community settings, and personal interactions warrants a place on the agendas of business educators. 


\section{AUTHOR BIOGRAPHY}

William W. Arnold is a Professor in the Business Division of Seaver College, Pepperdine University, Malibu, California where he teaches business strategy, servant leadership, and management theory and practice. Dr. Arnold held executive positions with several major health systems where he led revitalization and turnaround. A champion of authenticity in leadership, Dr. Arnold presented his experiences in The Human Touch. In engaging with students, he illustrates business principles by drawing on examples from his career. Dr. Arnold holds Doctoral, Master's, and Bachelor's degrees, respectively, from Pepperdine University, University of California, Los Angeles, and the University of Washington.

\section{REFERENCES}

The 2016 millennials impact report: Wave 1 trends. (2016). Washington, DC: The Case Foundation. Retrieved from http://fi.fudwaca.com/mi/files/2016/06/MIR2016-061616-TRENDS WEB.pdf

Almquist, E., Senior, J, \& Bloch, N. (2016). The elements of value. Harvard Business Review.

Bailey, C., \& Madden, A. (2016). What makes work meaningful - or meaningless. MIT Sloan Management Review.

Brafman, O., \& Beckstrom, R.A. (2006). The starfish and the spider: The unstoppable power of leaderless organizations. New York, NY: Penguin.

Catalyst. (2015). Revealing the real millennials: career expectations. Catalyst Knowledge Center. Retrieved from http://www.catalyst.org/knowledge/revealing-real-millennials-career-expectations

Chandler, J. (2015). Volunteer Trends. Retrieved from https://www.councilofnonprofits.org/thought-leadership/volunteer-trends

El-Attarash, F. (2015). Millennials and the call to public service. GovLoop.

Fry, R. Millennials overtake baby boomers as America's largest generation. Retrieved from http://www.pewresearch.org/facttank/2016/04/25/millennials-overtake-baby-boomers/

Godfrey, P.C., Illes, L.M., \& Berry, G.R. (September). Creating breadth in business education through service-learning. Academy of Management Learning and Education. 4(3), 309-323.

Jenkin, M. (2015). Millennials want to work for employers committed to values and ethics. The Guardian, Sustainable Business Leadership section.

Kaifi, B.A., Nafei, W.A., Khanfar, N.M., \& Kaifi, M.M. (2012). A multi-generational workforce: Managing and understanding millennials. International Journal of Business and Management, 7(24).

Maslow, A. (1954). Motivation and personality. New York, NY: Harper.

Meister, J.C., \& Willyerd, K. (2010). Mentoring millennials, Harvard Business Review.

Millennials and work. (2015). JC Global Services/HR Consulting. Retrieved from http://jcglobalservices.com /millennials$\% \mathrm{D} 0 \% \mathrm{~B} 0$ nd-work/

Millennials at work: Reshaping the workplace. (2008). PriceWaterhouseCoopers.

Moffat, J. (2015). The 7 positive qualities of millennials that can help you improve your business. Entrepreneur.

National and Community Service. (2014). Volunteering and civic engagement among millennials. Retrieved from https://www.volunteeringin America.gov/special/Millennials

Poon, P., Chan, T.S., \& Zhou, L. (2011). Implementation of service-learning in business education: Issues and challenges. Journal of Teaching in International Business. 22(3).

Smith, S.O. (2014). How Maslow's hierarchy of needs influences employment engagement. Retrieved from http://www.hrzone.com/community/blogs/steve-smith-0/how-maslows-hierarchy-of-needs-influences-employeeengagement

Solomon, M. (2016). You've got millennial employees all wrong: Here are the four things you need to know now. Forbes.

Strong, E. K. (1925). Theories of selling. Journal of Applied Psychology, 9, 75-86.

Sullivan, P., \& Clolery, P. (2014). Volunteers hiding in plain sight. The Nonprofit Times. Retrieved from http://www.thenonprofittimes.com/news-articles/volunteers-hiding-in-plain-sight/

Ukleja, M., \& Jackson, G. (2015). Why your leadership style isn’t working with Millennials. Leadership TRAQ, p.1. Retrieved from http://leadershiptraq.com/?s=Why+Your+Leadership+Style +Isn $\% 27 \mathrm{t}+$ Working\&image. $\mathrm{x}=0$ \&image. $y=0$

U.S. Bureau of Labor Statistics. (2016). Volunteering in the United States, 2015. Retrieved from www.bls.gov/newsrelease/volun.nr0.htm

U.S. Chamber of Commerce Foundation. (2012). The Millennial Generation Research Review. Retrieved from https://www.uschamberfoundation.org/reports/millennial-generation-research-review

Zenisek, E., \& Stinnett, M. (2014). Why millennials should ditch corporate jobs for public service. Fortune.

Zhou, J. (2016). Employee engagement hierarchy: How it works. Retrieved from https://soapboxhq.com/blog /employeeengagement-hierarchy 